into ninety-two elements of the periodic system, and all these ninety-two are recognised now to be aggre. gates of two simpler electrical units-positively charged protons and negatively charged electrons. Nevertheless, it is interesting to note that chemistry, in its development as a science from alchemy as an art, has passed through four distinct stages, in each of which one of the four elements of Aristotle has been dominant (see Nature, March 10, p. 354).

JusT as atmospheric air was found by Raleigh and Ramsay to contain traces of unsuspected elementsargon, neon, krypton and xenon-so ordinary water has recently been shown to have present in it a minute quantity of a novel compound-heavy water. Each hydrogen atom in heavy water comprises two protons and two electrons, or twice the quota of an ordinary hydrogen atom, and this increased complexity involves a significant change in chemical as well as in physical properties. Pure heavy water, prepared by a series of fractional electrolyses, has a density more than ten per cent higher than that of ordinary water. It freezes at $3 \cdot 8^{\circ}$ and boils at $101 \cdot 6^{\circ} \mathrm{C}$. It retards the development of plant life, and proves fatal to certain lower species of animal life, such as tadpoles and flat-worms. What its effect, in pure and diluted form, upon the human organism may be is at present merely a matter of interesting speculation. A very interesting survey was given of the views held on the nature of the elements from the earliest period to the present day, and Prof. Kendall suggested that in the future a further phase of development, corresponding with the fifth element of Aristotle, the quintessence or the ether, which survived the other four elements by a century, might recognise the greater importance of radiant energy in chemical processes.

\section{Accidents and their Prevention}

A Chadwick public lecture on "The Causes and Prevention of Human Accidents" was delivered by Dr. C. S. Myers, principal of the National Institute of Industrial Psychology, on March 12. Hitherto accidents in factories and on the road have been too often attributed merely to recklessness and carelessness and to dangerous conditions. More than 50 per cent of factory accidents (fatal and non-fatal) are found not to be due to dangerous machinery; and it has been estimated that, however much better machinery be guarded, the present factory accident rate of more than 106,000 per annum is unlikely to be seriously reduced by these measures or by more extensive use of safety-first posters. On the road, in spite of improved signals, car controls, regulated speeds of traffic and better lay-out of roads, 216,000 were injured and more than 7,000 killed in Great Britain through car accidents in 1933. At least 80 per cent of all such fatal accidents are attributable to the 'human factor', the study of which in occupational life is the concerm of the industrial psychologist. Accidents are not uniformly spread over the population whose actions may give rise to them. In each of two American investigations, it was found that about a half of the total accidents incurred by trams and omnibuses were confined to about a third of their drivers. In England, the scores obtained in selection tests for the motor driver devised by the National Institute of Industrial Psychology, have proved to be so highly correlated with the records of the safe driving of motor drivers on the roads, that one well-known insurance company has recently offered a ten per cent reduction in the annual premium for accident insurance to those who have passed these tests satisfactorily. Selection methods, however, must be supplemented by adequate knowledge, which can be obtained only by systematic training.

\section{New Land in the Antarctic}

Consul Lars Christensen, the Norwegian whaling expert who has done much to encourage Norwegian exploration in the Antarctic, left Cape Town in the whaler Thorshavn in December last year for the south. He has now returned to Montevideo and, according to the Times, announces the discovery of a new stretch of coast line 150 miles in extent, in lat. $72^{\circ} \mathrm{S}$. Unfortunately, the longitude is not given but the land would seem to lie in the unknown sector south of Bouvet Island between Princess Ragnhild Land on the east and Crown Princess Martha Land on the west. The hypothetical coastline was there drawn in approximately the latitude of the new discovery, which has been named Princess Astrid Land. A further note in the dispatch in reference to soundings in deep water on the supposed site of land suggests that some earlier discoveries may have to be moved south, but no details are yet available.

\section{A New Antarctic Expedition}

IT is announced in the Times that a British Antarctic Expedition will leave England in September for the western side of Graham Land. It will be led by Mr. J. R. Rymill, of the recent Watkins Greenland expedition, who will be accompanied by fourteen men most of whom have had experience in Greenland. They include Messrs. W. E. Hampton, Q. Riley, A. Stephenson, and E. Bingham. A vessel of about 120 tons, to be manned by the members of the expedition, will sail via Deception Island in the South Shetlands to Wilhelmina Bay in North Graham Land whence, after a reconnaissance by aeroplane, a sledge journey will be made along the east coast to Crane Channel and back. Later in the summer, the ship will be taken farther south and a base for two winters will be sought in Marguerite Bay, or farther south in Graham Land or possibly Hearst Land. If a safe harbour cannot be found, the ship will return to Deception Island leaving most of the expedition at a land station. From the southern base a sledge journey will start eastward in October 1935, returning about March 1936. It is hoped that this journey will settle the problem of the western coast line of the Weddell Sea. In the following summer, sledge journeys, supplemented by aeroplane flights, will be made westward to Charcot Island and beyond if possible. The expedition hopes to retum to England in May 1937. This ambitious project, which should 
solve some of the outstanding problems in Antaretic discovery, is estimated to cost no more than $£ 15,000$, of which the British Government is giving $£ 10,000$ and the Royal Geographical Society $£ 1,000$.

\section{Sir Everard im Thurn Memorial Scholarship}

THE council of the Scottish Anthropological Society proposes to create a permanent memorial of the late Sir Everard im Thurn by founding a lectureship in anthropology. Sir Everard im Thurn was the first president of the Edinburgh and Lothians Branch of the Royal Anthropological Institute, an office which he held from 1924 until 1932, and was one of the first to advocate the formation of a Scottish national society for the advancement of anthropological teaching and research. Sir Everard's distinction as an anthropologist has been widely recognised. $\mathrm{He}$ was the author of the standard work on the Indians of Guiana, contributed numerous papers on anthropological subjects to scientific journals, and was president of the Royal Anthropological Institute in 1919-21. It is intended that the Sir Everard im Thurn memorial lecture should be delivered annually on the date of the annual general meeting of the Society by an anthropologist of note. For this purpose, it is stated in an appeal issued by the memorial committee, of which Prof. H. J. Rose, president of the Society, is chairman, a capital sum of $£ 500$ will be required to meet the annual expenses. Part of this sum has already been provided, but further subscriptions are invited to make up the amount. In the meantime, arrangements have been made for the delivery of the first lecture on May 22, 1934, when Dr. R. R. Marett will lecture on "Sir Everard im Thurn as Anthropologist and as Man". Contributions to the fund should be addressed to the honorary treasurer of the Society, Mr. J. B. Mackay, 30 St. Alban's Road, Edinburgh.

\section{Work of Geological Surveys}

THE presidential address of Sir Thomas Holland at the annual general meeting of the Geological Society on February 16 was mainly devoted to an examination of the organisation of the geological surveys of the British Empire and the United States. $\mathrm{He}$ emphasised the fact that the real object of every such survey is the mineral development of the country, scientific results being obtained as by-products and used as a means to attaining the economic object in view. The work of preparing a geological map requires the co-operation of various specialists of at least seven kinds. With a director and his assistant, a curator and a chemist, the minimum number of scientific officers required for a survey like that of India, for example, is found to be about 21. Below this standard an organisation is scientifically inefficient and economically wasteful. The colonies separately might not be able, for financial reasons, to maintain this standard, but the difficulty could be partially met, as in the Federated Malay States, by a federation of officers in geographically related groups. Important functions of a survey are the classification of public lands and the compilation and analysis of mineral statistics. The director should be well acquainted with the trend of mineral development, watching imports for indications that the country might itself produce certain minerals and by-products. He should therefore be the adviser of his Government on questions of mineral policy, whether in purely economic matters or in the development and conservation of minerals that are essential for the production of munitions of war.

\section{Science and Society}

ThE third Hobhouse memorial lecture, on the subject, "Rational and Irrational Elements in our Society", was delivered at Bedford College for Women on March 7 by Prof. Karl Mannheim, formerly professor of sociology in the University of Frankforton-Main, and now lecturer in sociology at the London School of Economies and Political Science. The main theme of the lecture was the problem created for contemporary society through the disproportion between the range of man's technical knowledge, and his moral qualities and rational insight into the social mechanism which it is the task of members of society to control. Society must break down unless this grave disproportion be remedied. Owing to the correlation of the growth of certain moral and spiritual elements with certain features in society, the problem is amenable to scientific treatment. The question to be answered is what are the elements in an industrialised society which tend to heighten rationality and at the same time to promote irrationality. Two senses of rationality must be distinguished. Substantial rationality relates to thinking and understanding, to the cogitative elements in general; functional rationality relates to the organisation of activities for the attaining of given ends calculated from the point of view of a given observer. Modern industrialised society has revealed the power to plan and control possessed by those who are emotion. ally primitive. Our society is faced with the problem of planning the man who has to plan men. Its future depends upon the group within society which has the ability to control, and the energy to subdue the irrational elements.

\section{Birmingham Museum}

THe City of Birmingham Museum and Art Gallery, which celebrates its jubilee this year with a series of special exhibitions, the first of which was opened on February 24, may be said to have had its origin in the presentation of Edward Coleman's painting, "Dead Game", by a body of subscribers in 1864, an Art Gallery formed in a room of the Free Library being opened to the public in August three years later. In $1870, £ 1,000$ was raised towards the formation of a Museum of Industrial and Decorative Art, but the establishment of a natural history museum was not mooted until 1887 . The project received little support as Dr. Sans Cox had already established a collection at Queen's College, which was later handed over to the corporation. In 1904, however, the City Council decided to allocate the upper floor of the new Art Gallery building, facing Congreve Street, for a natural history museum. 